Original Article

\title{
A Physiological behavior and tolerance of Lactuca sativa to lead nitrate and silver nitrate heavy metals
}

\author{
Comportamento fisiológico e tolerância de Lactuca sativa aos metais pesados nitrato \\ de chumbo e nitrato de prata
}

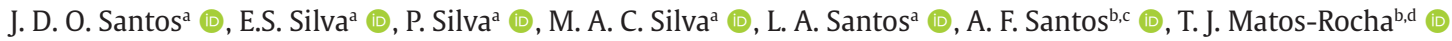 \\ and J. M. S. J. Pavão ${ }^{\mathrm{b}^{*}}$ (D) \\ a Universidade Federal de Alagoas, Programa de Pós-graduação em Agricultura e Meio Ambiente, Arapiraca, AL, Brasil

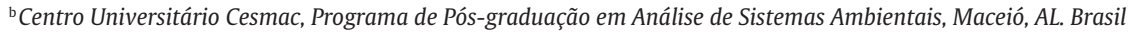 \\ ' Universidade Estadual de Alagoas - UNEAL, Arapiraca, AL, Brasil \\ dUniversidade Estadual de Ciências da Saúde de Alagoas - UNCISAL, Maceió, AL, Brasil
}

\begin{abstract}
This study goal to evaluate the effects of different concentrations of lead $(\mathrm{Pb})$ and silver $(\mathrm{Ag})$ on germination, initial growth and anatomical alterations of Lactuca sativa L. Plants use various mechanisms to reduce the impacts caused by anthropic action, such as xenobiotic elements of soils and water contaminated by heavy metals. These metals were supplied as lead nitrate and silver nitrate and the following treatments were established: control for both metals, maximum dose of heavy metals, for arable soils, allowed by the National Council of the Environment $\left(\mathrm{Ag}=25 \mathrm{mg}\right.$. $\mathrm{Kg}^{-1}$, $\mathrm{Pb}=180 \mathrm{mg}$. Kg-1 $)$, double $\left(\mathrm{Ag}=50 \mathrm{mg}\right.$. $\left.\mathrm{Kg}^{-1}, \mathrm{~Pb}=360 \mathrm{mg} \cdot \mathrm{Kg}^{-1}\right)$ and triple $\left(\mathrm{Ag}=75 \mathrm{mg} . \mathrm{Kg}^{-1}, \mathrm{~Pb}=540 \mathrm{mg} \cdot \mathrm{Kg}^{-1}\right)$ of this dosage. Vigor and germination tests of the seeds and possible anatomical changes in the leaves and roots of lettuce plants were performed. The species showed a high capacity to germinate under $\mathrm{Pb}$ and $\mathrm{Ag}$ stress, and the germination was never completely inhibited; however, the germination decreased with increasing $\mathrm{Pb}$ concentrations, but not under Ag stress. The use of increasing doses of metals reduced seed vigor and increased chlorophyll content. An increase in biomass was also observed in plants from treatments submitted to $\mathrm{Pb}$. The phytotoxic effects of metals were more pronounced at 15 days after sowing. Anatomically, L. sativa was influenced by metal concentrations, and had a reduction of up to $79.9 \%$ in root epidermis thickness at the highest $\mathrm{Pb}$ concentration, although some structures did not suffer significant changes. The results suggest that $L$. sativa presents tolerance to high concentrations of heavy metals, showing possible mechanisms to overcome the stress caused by these metals. In this research lettuce possibly used the mechanism of exclusion of metals retaining $\mathrm{Pb}$ and $\mathrm{Ag}$ in the roots preserving the photosynthetic apparatus in the aerial part of the plants. In general, the chemical element $\mathrm{Pb}$ was more toxic than $\mathrm{Ag}$, in these experimental conditions.

Keywords: lettuce, heavy metals, soil contamination, plant growth, tissue plasticity.
\end{abstract}

\begin{abstract}
Resumo
Este estudo teve como objetivo avaliar os efeitos de diferentes concentrações de chumbo ( $\mathrm{Pb}$ ) e prata $(\mathrm{Ag})$ na germinação, crescimento inicial e alterações anatômicas de Lactuca sativa L. As plantas utilizam vários mecanismos para reduzir os impactos causados pela ação antrópica, como elementos xenobióticos de solos e água contaminada por metais pesados. Esses metais foram fornecidos como nitrato de chumbo e nitrato de prata e foram estabelecidos os seguintes tratamentos: controle para ambos os metais, dose máxima de metais pesados, para solos cultiváveis, permitida pelo Conselho Nacional do Meio Ambiente ( $\left.\mathrm{Ag}=25 \mathrm{mg} \cdot \mathrm{Kg}^{-1}, \mathrm{~Pb}=180 \mathrm{mg} \cdot \mathrm{Kg}^{-1}\right)$, dobro $\left(\mathrm{Ag}=50 \mathrm{mg} \cdot \mathrm{Kg}^{-1}, \mathrm{~Pb}=360 \mathrm{mg} \cdot \mathrm{Kg}^{-1}\right)$ e triplo $\left(\mathrm{Ag}=75 \mathrm{mg} \cdot \mathrm{Kg}^{-1}\right.$, $\left.\mathrm{Pb}=540 \mathrm{mg} \cdot \mathrm{Kg}^{-1}\right)$ desta dosagem. Foram realizados testes de vigor e germinação das sementes e possíveis alterações anatômicas nas folhas e raízes das plantas de alface. A espécie apresentou alta capacidade de germinar sob estresse de $\mathrm{Ag}$ e $\mathrm{Pb}$, e a germinação nunca foi completamente inibida; entretanto, a germinação diminuiu com o aumento das concentrações de $\mathrm{Pb}$, mas não sob estresse de $\mathrm{Ag}$. O uso de doses crescentes dos metais, reduziu o vigor das sementes e aumentou o teor de clorofila. Também foi observado aumento da biomassa nas plantas a partir dos tratamentos submetidos ao $\mathrm{Pb}$. Os efeitos fitotóxicos dos metais foram mais acentuados aos 15 dias após a semeadura. Anatomicamente, $L$. sativa foi influenciada pelas concentrações de metais, e teve uma redução de até 79,9\% na espessura da epiderme radicular na maior concentração de Pb, embora algumas estruturas não tenham sofrido alterações significativas. Os resultados sugerem que $L$. sativa apresenta tolerância a altas concentrações de metais pesados, mostrando possíveis mecanismos para superar o estresse causado por esses metais. Nesta pesquisa a alface possivelmente utilizou o mecanismo de exclusão de metais retendo $\mathrm{Pb}$ e $\mathrm{Ag}$ nas raízes preservando o aparato fotossintético na parte aérea das plantas. De forma geral o elemento químico $\mathrm{Pb}$ se mostrou mais tóxico que $\mathrm{Ag}$, nestas condições experimentais.
\end{abstract}

Palavras-chave: alface, metais pesados, contaminação do solo, crescimento da planta, plasticidade do tecido.

*e-mail: jesse.marques@cesmac.edu.br

Received: May 4, 2020 - Accepted: December 14, 2020

This is an Open Access article distributed under the terms of the Creative Commons Attribution License, which permits unrestricted use, distribution, and reproduction in any medium, provided the original work is properly cited. 


\section{Introduction}

Lettuce (Lactuca sativa L.) is classified in the Asteraceae family, and it is one of the most consumed vegetables in Brazil and in the world. Due to its accumulating characteristic, it is subject to contamination by heavy metals dissolved in the soil solution (Silva et al., 2019; Eissa and Negim, 2018).

Contaminant metals in the soil can be classified as heavy metals or trace elements. Heavy metals are elements that normally give high toxicity to humans; among them, stand out the lead, cadmium, silver, mercury and chromium (Suryawanshi, et al., 2016; Baroni et al., 2020). Trace elements, on the other hand, are metals with lower toxicity and are often present in low concentrations, and some of them are considered biologically essential; however, some of these metals in specific situations may cause problems to ecosystems, causing pollution to water and soil (Ribeiro et al., 2019).

The fertilizers, metallurgical, mining, chemical, waste disposal, sewage sludge, tannery sludge, and fossil fuels industriesare the main sources of soil contamination by heavy metals (Ćwieląg-Drabek, 2020; Eissa and Negim, 2018). The possibility that the metals enter human food raises many concerns since they can be in leafy tissues present in vegetables such as lettuce, bringing risks to human health (Eissa and Negim, 2018).

It has long been known that high concentrations of heavy metals such as silver, lead, mercury, among others, are responsible for causing numerous carcinogenic diseases, as well as other aggravating factors such as damage to the central nervous and the hepatic, renal, hematopoietic and skeletal systems (Kim et al., 2015; Shahbazi et al., 2017). For this reason, some countries have established boundaries and laws that govern the concentrations of heavy metals in agricultural soils.

The absorption, distribution and action mechanisms of heavy metals in plants depend on several factors, including species or varieties of the same species, plant development stage, chemical species of the element, metal concentration, time of exposure, soil $\mathrm{pH}$, and organic matter content (Pendias, 2010; Baghaie and Fereydoni, 2019).When the heavy metals are absorbed by the roots, they accumulate mainly in the cell wall (Azevedo et al., 2019), and the exoderm and endoderm become a barrier to the movement of these ions (Tylová et al., 2017; Ismael et al., 2019).

When exposed to heavy metal contamination, lettuce undergoes significant interference in physiological processes. Therefore, this study aimed to evaluate the effect of different concentrations of lead nitrate $\left(\mathrm{Pb}\left(\mathrm{NO}_{3}\right)^{2}\right)$ and silver nitrate $\left(\mathrm{AgNO}_{3}\right)$ on the emergence, initial growth and anatomical changes in L. sativa.

\section{Material and Methods}

\subsection{Experiment Installation}

The experiment was carried out in a greenhouse (9 42'03.9"S 36 41'13.1"W and 324m altitude), using lettuce (L. sativa), cv 'babá de verão', purchased at a store of agricultural products in the municipality of Arapiraca, (Alagoas State, Brazil). The average temperatures inside the greenhouse in the months of the experiment (June at September) were $6 \mathrm{am}$ at $12 \mathrm{pm}\left(25.8^{\circ} \mathrm{C}\right)$ and $12 \mathrm{pm}$ at $6 \mathrm{pm}\left(23.7^{\circ} \mathrm{C}\right)$. And relative air humidity of $69 \%$.

The experimental unit consisted of a container filled with $500 \mathrm{~g}$ of soil (Medium texture), in which the solutions of lead $(\mathrm{Pb})$, in the form of lead nitrate $\left(\mathrm{Pb}\left(\mathrm{NO}_{3}\right)_{2}\right)$ and silver $(\mathrm{Ag})$ in the form of silver nitrate $\left(\mathrm{AgNO}_{3}\right)$, were applied in 3 increasing concentrations constituting the respective treatments. The watering shift that was used these solutions occurred in the morning, between $7 \mathrm{am}$ and $8 \mathrm{am}$. The standard concentration of each metal was based on the maximum value allowed by the Resolution 460/2013 (CONAMA, 2013 - National Environment Council) for agricultural soils $\left(\mathrm{Ag}=25 \mathrm{mg} \cdot \mathrm{Kg}^{-1}, \mathrm{~Pb}=180 \mathrm{mg} \cdot \mathrm{Kg}^{-1}\right)$, and this value was doubled $\left(\mathrm{Ag}=50 \mathrm{mg} \cdot \mathrm{Kg}^{-1}, \mathrm{~Pb}=360 \mathrm{mg} \cdot \mathrm{Kg}^{-1}\right)$ and tripled $\left(\mathrm{Ag}=75 \mathrm{mg} \cdot \mathrm{Kg}^{-1}, \mathrm{~Pb}=540 \mathrm{mg} \cdot \mathrm{Kg}^{-1}\right)$, in addition to the control groups for the two metals. The lettuce chemical fertilization was carried out using NPK 4:14:8, applied at the time of planting.

Each plot consisted of four containers, in which sixteen seeds were sown per plot. At 15 DAS (days after sowing), thinning was performed, leaving only four plants per plot. The evaluations were carried out at 15, 21 and 35 DAS.

\subsection{Germination and evaluation of seed vigor}

The Emergence Speed Index, Emergence Time and Emergence Percentage were determined using the following formulas, respectively:

$$
\mathrm{ESI}=(\mathrm{G} 1 / \mathrm{N} 1)+(\mathrm{G} 2 / \mathrm{N} 2)+\ldots+(\mathrm{Gn} / \mathrm{Nn}) ;
$$

where: ESI= Emergence Speed Index, $G=$ number of normal seedlings computed in the counts, and $\mathrm{N}=$ number of days from sowingto the first, second... umpteenth time of evaluation) (Maguire, 1962);

$$
\mathrm{tE}=(\mathrm{S} . \mathrm{ni} . \mathrm{ti}) / \mathrm{S} \text { ni ; }
$$

where: $\mathrm{tE}=$ the mean time of emergence, $\mathrm{ni}=$ the number of seedlings emerged at the $\mathrm{i}$-th day, and $\mathrm{t} i=$ time (days) (Labouriau, 1983);

$$
\mathrm{E}=(\mathrm{Ne} / \mathrm{Ae}) \cdot 100 ;
$$

where: $\mathrm{E}=$ emergence percentage, $\mathrm{Ne}=$ number of emerged seedlings, and $\mathrm{Ae}=$ total number of seeds placed to emerge (Brasil, 2009).

The analyses were performed from the first to the eleventh day after sowing.

\subsection{Growth analysis and chlorophyll and dry biomass determination}

Plant height, leaf area, and dry matter were obtained to analyze the growth of the crop. Leaf area was calculated by the non-destructive method, using leaf number, length, width and correction factor of 0.68 , using the equation:

$$
\mathrm{AF}=[(\mathrm{C} \times \mathrm{L}) / 2 \times \mathrm{CF} \times \mathrm{NF}]
$$


Where: $\mathrm{C}=$ leaf length in $\mathrm{cm}, \mathrm{L}=$ leaf width in $\mathrm{cm}$, $\mathrm{CF}=$ correction factor, and $\mathrm{NF}=$ number of leaves per plant. The SPAD index readings were performed in the morning, on fully expanded terminal leaves by using the indirect chlorophyll meter SPAD-502 (Soil Plant Analysis Development), Konica Minolta Camera Co. Ltd. Japan. Three leaves were randomly analyzed in each plot with ten measurements on each leaf.

At the end of the experimental period, all plants were collected, divided into root and aerial part (shoots), conditioned in Kraft paper bags, dehydrated in a forced air ventilation oven at $70^{\circ} \mathrm{C}$ for 48 hours, and then weighed on an analytical balance (Mars AD500) to obtain the dry biomass of the respective parts.

\subsection{Anatomical analyses}

For anatomy analysis, five leaves and five roots of each treatment were randomly collected at 35 DAS. The samples were fixed in F.A.A. ${ }_{70 \%}$ (Johansen, 1940) for 48 hours, and later they were stored in $70 \%$ ethyl alcohol. Cross sections were obtained manually, and root cuts were clarified in $1 \%$ sodium hypochlorite solution, washed three times for 5 minutes in distilled water, stained with $0.05 \%$ toluidine blue (Sakai, 1973) and mounted on 50\% aqueous glycerol (Kraus; Arduin, 1997).

The slides were photographed with a camera (Canon Powershot A630) coupled to the optical microscope (Nova 107) and analyzed in the Image Tool software version 3.0. The anatomical tissues evaluated in the leaves were: epidermis thickness of the abaxial face (EAB), epidermis thickness of the adaxial face (EAD), chlorophyll parenchyma thickness $(\mathrm{CP})$, vascular bundles thickness, and the distance between vessels. In the root, epidermis thickness, cortical parenchyma thickness, and vascular bundle thickness were observed.

\subsection{Statistical analyses}

From the raw data (data set) the normality test was applied by Shapiro-Wilk (Shapiro and Wilk, 1965). The deviances were estimated according to data distribution for each factor and interaction, as well as for null and saturated models, whence residual deviance derives. Inferences of the deviance analysis for binomial distribution were based on Scott Knott test, because the dispersion parameter is known. All the analysis were performed with software R version 3.4.1(R Core Team, 2018), considering the significance level of $\alpha=0.01$ for all applied tests. A completely randomized design with 50 replicates, in a factorial scheme $2 \times 4$ (metals $\mathrm{x}$ concentrations), was used.

\section{Results}

The data, when submitted to variance normality and homogeneity tests presented normal distribution and it was not necessary to transform them. After obtaining ANOVA only for the variable average time of germination, there was interaction, the other variables the behavior was due only to the functions of the elements $\mathrm{Pb}$ and $\mathrm{Ag}$.

\subsection{Emergence and growth}

Seed emergence and vigor test showed an interaction between the metals for both the emergence speed index (ESI) and emergence percentage (E). Both $\mathrm{Pb}$ and $\mathrm{Ag}$
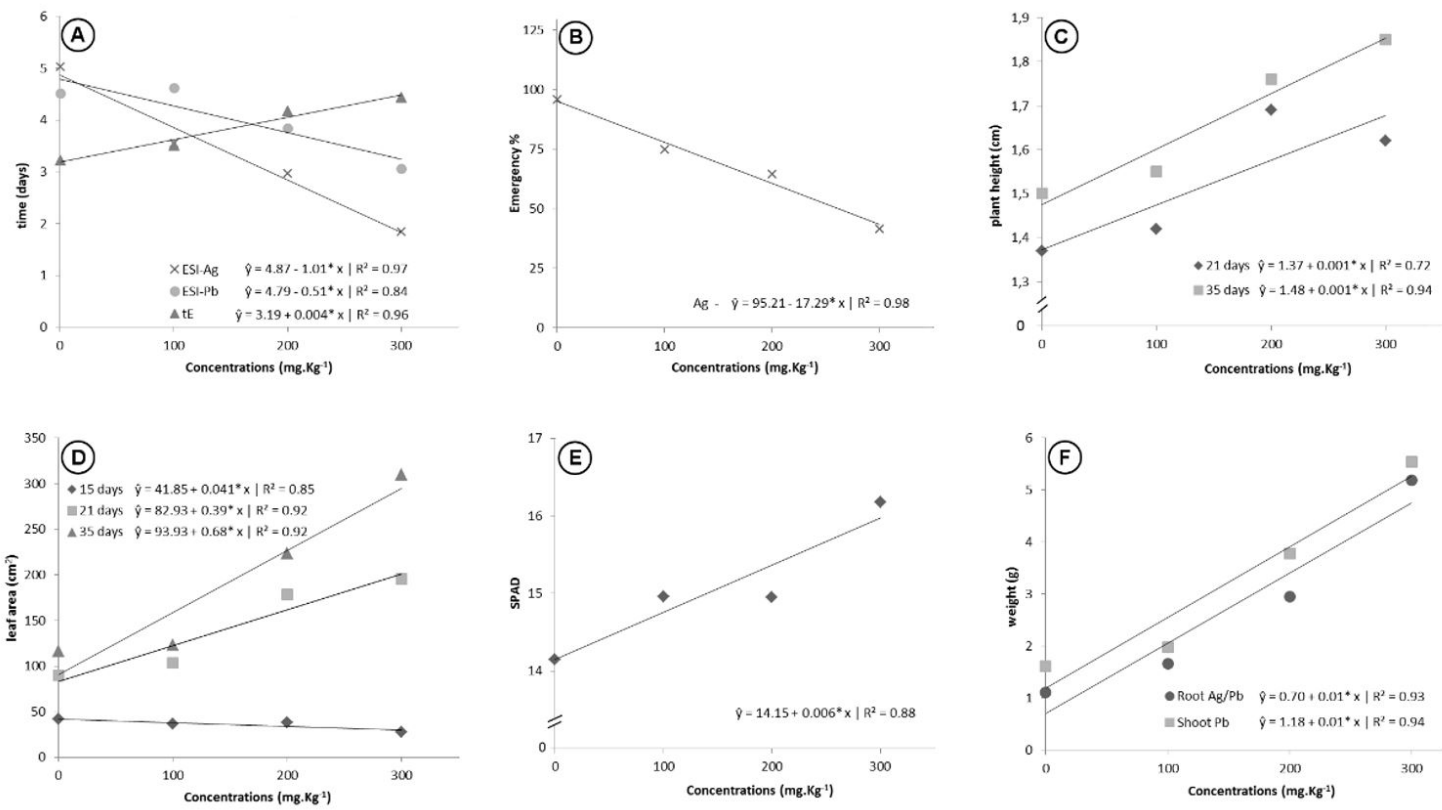

Figure 1. Germination and growth characteristics of lettuce plants subjected to increasing lead and Ag concentrations. A) Emergence speed index and emergence mean time; B) Emergence percentage; C) Plant height as a function of lead and silver concentrations; D) Behavior of leaf area in plants subjected to lead; E) SPAD as a function of lead and silver concentrations; F) Weight of dry matter. Each point on the graphs represents an average of 50 repetitions. The standards variations vary between \pm 2.5 and \pm 6.8 around the average from the graphs at the different points. 
reduced the ESI; however, as their concentrations were increased, there was a higher decrease when $\mathrm{Ag}$ was used (Figure 1A). There was no difference or interaction, being only significant the metals concentration variable $(\mathrm{Pb}$ and $\mathrm{Ag}$ ), being used, in regression, for the construction of Figure $1 \mathrm{~A}$, representing the pattern both metals. The tE was affected by both metals, increasing as the concentrations of these metals were increased. The percentage of $\mathrm{Pb}$ emergence has not been explained, so the graph refers only to the percentage of $\mathrm{Ag}$. In this case, the emergence percentage was not affected by the different concentrations of $\mathrm{Pb}$, whereas the Ag concentrations significantly reduced this factor, increasing it as the concentrations were increased (Figure 1B).

The different concentrations of heavy metals did not significantly affect plant height in the first 15 DAS, whereas the analyses performed at 21 and 35 DAS (Figure 1C) showed a linear behavior, expressing an elongation in the stem as the $\mathrm{Pb}$ and $\mathrm{Ag}$ concentrations were increased.

No significant differences were observed in leaf area in plants subjected to $\mathrm{Ag}$ concentrations, and there was no interaction between the analyzed factors either. However, at 15 DAS, leaf area was inversely proportional to $\mathrm{Pb}$ concentrations, and at 21 and $35 \mathrm{DAS}$, leaf area was directly proportional to these concentrations, increasing the leaf as the highest concentrations of heavy metals were applied (Figure 1D).

As there was no significant difference between $\mathrm{Pb}$ and $\mathrm{Ag}$, but there were different options, the graph was then constructed from the linear regression of SPAD and customs, representing the pattern for both metals. (Figure 1E).

Ag concentrations provided no significant increases or decreases in shoot dry biomass production. Pb increased the biomass as the highest concentrations were applied
(Figure 1F). This behavior was also observed for root dry mass for both metals (Figure $1 \mathrm{~F}$ ).

\subsection{Anatomy}

Analyzing the micrographs of the anatomical slides, it is noticeable that the structural aspect of the tissues has not been visually altered (Figure 2 ), but the differences between the metals used and their respective concentrations can be visualized on a micrometric scale (Table 1 ).

An interesting fact that occurred in this work, it is possible to observe when comparing Figures $2 \mathrm{~A}$ and $2 \mathrm{G}$, the tissue changes are clear when the lettuce plants come into contact with the different concentrations of lead and silver nitrate. Where, from Figure 2 B, ontogenesis of accessory vessels occurs, as well as greater distance between the vascular bundles.

Visually, with the increase in the concentrations of metals, those conduction vessels (xylem and phloem), present discreet robustness and this structure are perceived, mainly from Figure 2B. Vessels xylem in the details. In Figure 3C, the diameters of the vessels are quite pronounced, when compared with the vessel details of Figures 3 A-F. In Figure 3G, the vessels have higher density when compared to Figure $3 \mathrm{C}$.

For the epidermis thickness of the adaxial face (EAD) of L. sativa leaves, more compared to their controls, pronounced differences were found at the highest concentration of $\mathrm{Ag}$, in this case, was observed an increase of $15.7 \%$. Observed again an increase of $24.9 \%$ in the EAD in plants subjected to the concentration of $180 \mathrm{mg}$. $\mathrm{Kg}^{-1}$ of $\mathrm{Pb}$, and a decrease of $51.8 \%$ in the EAD in those grown at the concentration of $360 \mathrm{mg} \cdot \mathrm{Kg}^{-1}$. There was no statistical difference regarding the EAD between plants
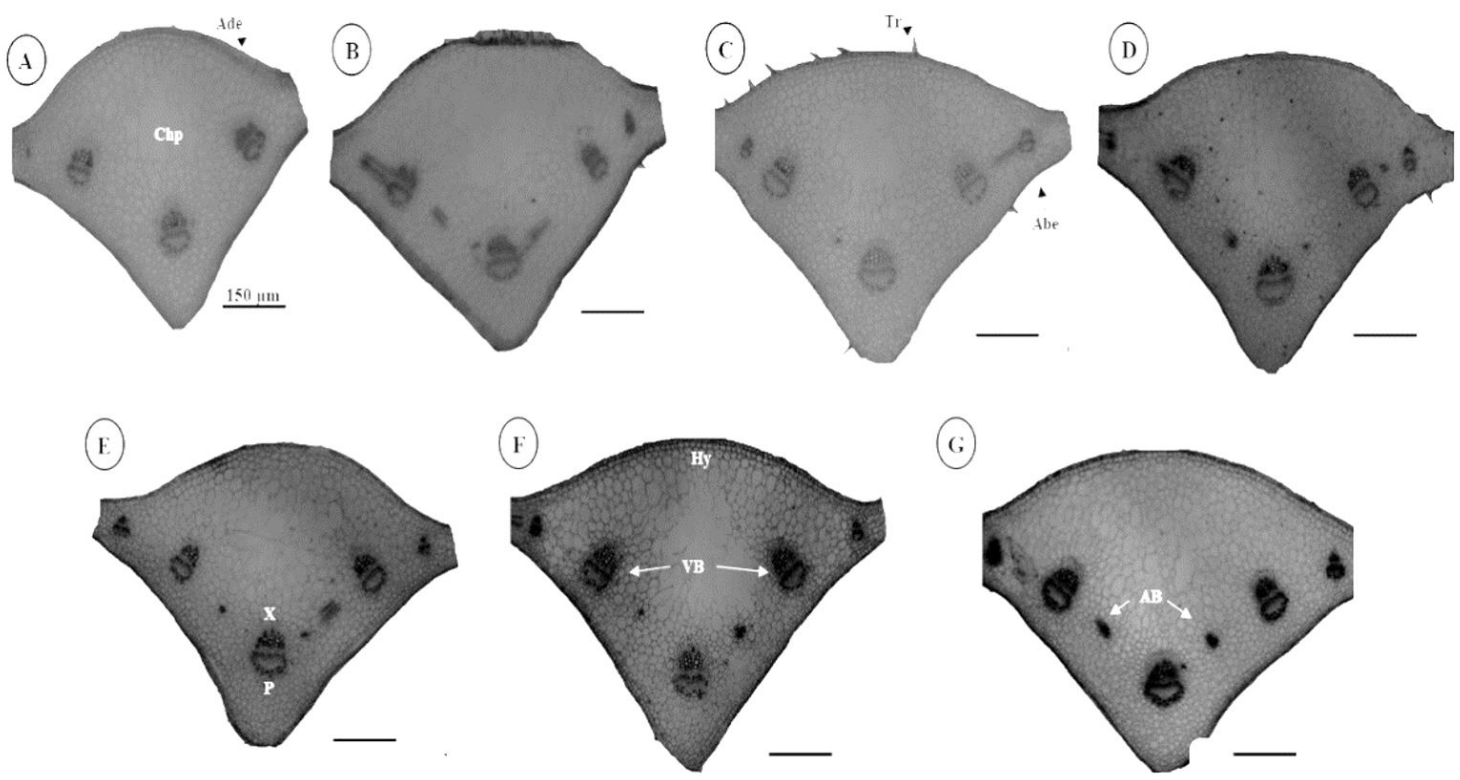

Figure 2. Leaves of lettuce under lead and silver nitrate concentrations. A: 0 mg.Kg-1 Pb and Ag; B: 12,5 mg.Kg-1 Ag; C: 25 mg.Kg-1 Ag; D: $37 \mathrm{mg} \cdot \mathrm{Kg}^{-1} \mathrm{Ag}$; E: $90 \mathrm{mg} \cdot \mathrm{Kg}^{-1} \mathrm{~Pb}$; F: $180 \mathrm{mg} \cdot \mathrm{Kg}^{-1} \mathrm{~Pb}$ and G: $270 \mathrm{mg} \cdot \mathrm{Kg}^{-1} \mathrm{~Pb}$. Ade: adaxial epidermis;Chp:Chlorophyll parenchyma; Tr:trichome; X: xylem; Abe: abaxial epidermins P: phoema Hy: Hypodermis; VB:vascular bundles; AB: Assesory bundles Bars 50um. 
Table 1. Means from the anatomy of stem and root tissues in L. sativa under concentrations $\mathrm{Pb}$ and $\mathrm{Ag}$.

\begin{tabular}{|c|c|c|c|c|c|c|}
\hline \multirow{2}{*}{$\begin{array}{c}\text { Analyzed } \\
\text { part }\end{array}$} & \multirow{2}{*}{ Tissue $(\mu \mathrm{m})$} & & \multicolumn{4}{|c|}{ Heave metal concentrations ${\text { mg. } \mathrm{Kg}^{-1} \text { * }}^{*}$} \\
\hline & & & $\mathbf{0}$ & 100 & 200 & 300 \\
\hline \multirow{6}{*}{ Root } & \multirow{2}{*}{ Epidermis } & $\mathrm{Ag}$ & $189.97 \mathrm{aA} * *$ & $129.57 \mathrm{bBC}$ & $172.39 \mathrm{a} A \mathrm{~B}$ & $114.55 \mathrm{aC}$ \\
\hline & & $\mathrm{Pb}$ & $175.36 a A$ & $201.59 \mathrm{aA}$ & $163.42 \mathrm{aA}$ & $97.50 \mathrm{aB}$ \\
\hline & \multirow{2}{*}{ Cortical parenchyma } & $\mathrm{Ag}$ & $334.84 \mathrm{aAB}$ & $430.87 \mathrm{aA}$ & $252.21 \mathrm{aB}$ & $357.48 \mathrm{aA}$ \\
\hline & & $\mathrm{Pb}$ & $381.98 a A$ & $367.92 \mathrm{aAB}$ & $298.95 \mathrm{aAB}$ & $276.45 b B$ \\
\hline & \multirow{2}{*}{ Thickness of vessels } & $\mathrm{Ag}$ & $325.85 a B$ & $382.76 \mathrm{bB}$ & $355.15 b B$ & $515.00 \mathrm{aA}$ \\
\hline & & $\mathrm{Pb}$ & $358.66 a \mathrm{~B}$ & $501.89 \mathrm{aA}$ & $451.65 \mathrm{aA}$ & $516.34 \mathrm{a} A$ \\
\hline \multirow{10}{*}{ Leaf } & \multirow{2}{*}{ Adaxial epidermis } & $\mathrm{Ag}$ & $28.66 \mathrm{aB}$ & $24.23 \mathrm{bC}$ & $24.55 \mathrm{aC}$ & $33.15 \mathrm{aA}$ \\
\hline & & $\mathrm{Pb}$ & $27.17 a B$ & 33.93aA & $22.35 \mathrm{aC}$ & $25.14 \mathrm{bBC}$ \\
\hline & \multirow{2}{*}{ Abaxial epidermis } & $\mathrm{Ag}$ & $22.78 \mathrm{aAB}$ & $17.87 \mathrm{bB}$ & $28.26 \mathrm{aA}$ & $23.55 \mathrm{aAB}$ \\
\hline & & $\mathrm{Pb}$ & $22.04 \mathrm{aA}$ & $24.08 \mathrm{aA}$ & $17.70 \mathrm{bA}$ & $22.54 \mathrm{aA}$ \\
\hline & \multirow{2}{*}{ Distance between vessels } & $\mathrm{Ag}$ & $629.53 \mathrm{aC}$ & $750.99 \mathrm{aB}$ & 817.12aAB & $881.53 \mathrm{aA}$ \\
\hline & & $\mathrm{Pb}$ & $629.56 a B$ & $648.22 \mathrm{bB}$ & $569.87 \mathrm{bB}$ & 861.70aA \\
\hline & \multirow{2}{*}{ Thickness of vessels } & $\mathrm{Ag}$ & $252.56 \mathrm{aB}$ & $275.42 \mathrm{aB}$ & $284.94 \mathrm{aB}$ & $353.44 \mathrm{aA}$ \\
\hline & & $\mathrm{Pb}$ & $278.06 \mathrm{aA}$ & $262.28 \mathrm{aAB}$ & $226.11 \mathrm{bB}$ & $271.58 \mathrm{bA}$ \\
\hline & \multirow{2}{*}{ Chlorophyll parenchyma } & $\mathrm{Ag}$ & $1827.25 \mathrm{aC}$ & $1983.65 \mathrm{aB}$ & 2067.62aB & 2243.27aA \\
\hline & & $\mathrm{Pb}$ & $1859.88 \mathrm{aB}$ & $1723.77 \mathrm{bB}$ & $1556.41 \mathrm{bC}$ & $2148.26 \mathrm{aA}$ \\
\hline
\end{tabular}

${ }^{*} 0 \%$ concentration is equivalent to the absence of the metal for both metals; $100 \%$ at $25 \mathrm{mg} \cdot \mathrm{kg}^{-1}$ and $180 \mathrm{mg} \cdot \mathrm{kg}^{-1} ; 200 \%$ at $50 \mathrm{mg} \cdot \mathrm{kg}^{-1} \mathrm{and}$ $360 \mathrm{mg} \cdot \mathrm{kg}^{-1}$; and $300 \%$ at $75 \mathrm{mg} \cdot \mathrm{Kg}^{-1}$ and $540 \mathrm{mg} \cdot \mathrm{Kg}^{-1}$ for Ag and Pb, respectively. ${ }^{* *}$ Means followed by the same lowercase letter, in the columns, and upper case, in the lines, do not differ by Scott Knott test at the 5\% significance level.

subjected to the concentrations of $50 \mathrm{mg} \cdot \mathrm{Kg}^{-1}$ of $\mathrm{Ag}$ and those grown at the concentration of $360 \mathrm{mg} \cdot \mathrm{Kg}^{-1}$ of $\mathrm{Pb}$. In plants grown at the concentration of $180 \mathrm{mg} \cdot \mathrm{kg}^{-1} \mathrm{of} \mathrm{Pb}$, the EAD was increased by $40 \%$, when compared to those subjected to $25 \mathrm{mg} \cdot \mathrm{Kg}^{-1}$ of Ag. At the maximum applied concentration, Ag caused an increase in EAD than when was $\mathrm{Pb}$ applied (Table 1).

Regarding the epidermis thickness of the abaxial face (EAB), there was no difference up to $75 \mathrm{mg} . \mathrm{Kg}^{-1}$ between the plants subjected to $\mathrm{Ag}$ and those from the control group, except at the concentration of $50 \mathrm{mg} \cdot \mathrm{Kg}^{-1}$, in which there was an increase of $58.1 \%$ in the EAB in comparison with the concentration of $25 \mathrm{mg} \cdot \mathrm{kg}^{-1}$. Regarding the effect of both metals, $\mathrm{Pb}$ concentrations had no significant effect on the EAB. $\mathrm{Pb}$ provided an increase of $34.7 \%$ in the $\mathrm{EAB}$ in plants grown at the concentration of $180 \mathrm{mg} \cdot \mathrm{Kg}^{-1}$ and a reduction of $37.4 \%$ at the concentration of $360 \mathrm{mg} \cdot \mathrm{Kg}^{-1}$, in comparison to the concentrations of $25 \mathrm{mg} \cdot \mathrm{kg}^{-1}$ and $50 \mathrm{mg} \cdot \mathrm{kg}^{-1}$ of Ag, respectively (Table 1 ).

Comparing the distances between vessels, the higher the concentration of Ag, the larger the distance between them. However, the distance between vessels in plants subjected to the concentration of $50 \mathrm{mg} . \mathrm{Kg}^{-1}$ of Ag did not differ from the distance found in plants subjected to 25 and $75 \mathrm{mg}$. $\mathrm{Kg}^{-1}$ of Ag, (Table 1). Regarding the $\mathrm{Pb}$, the largest distance was observed at the highest concentration. Comparing the effect of both metals, plants grown at concentrations of 25 and 50 mg.Kg-1 of Ag showed an increase of $15.9 \%$ and $43.4 \%$ in the distance between vessels, respectively, compared to those subjected to the concentrations of 180 and $360 \mathrm{mg} \cdot \mathrm{Kg}^{-1}$ of $\mathrm{Pb}$ (Table 1).

The thickness of vessel bundles in plants subjected to the $\mathrm{Ag}$ treatment showed no difference up to the concentration of $50 \mathrm{mg} . \mathrm{Kg}^{-1}$; however, in plants at the concentration of $75 \mathrm{mg} \cdot \mathrm{kg}^{-1}$, it was $39.9 \%$ higher than the thickness of vessels in plants from the control treatment. At $\mathrm{Pb}$ concentrations, there was no difference regarding this variable in plants subjected up to the concentration of $540 \mathrm{mg} \cdot \mathrm{Kg}^{-1}$, except for those under $360 \mathrm{mg} \cdot \mathrm{Kg}^{-1}$, which presented lower mean and did not differ from the plants of the $180 \mathrm{mg} \cdot \mathrm{Kg}^{-1}$ treatment. In contrast, the metals did not influence the thickness of vessels in plants at the concentration of $100 \%\left(25 \mathrm{mg} \cdot \mathrm{Kg}^{-1}\right.$ of Ag and $\left.180 \mathrm{mg} \cdot \mathrm{Kg}^{-1} \mathrm{of} \mathrm{Pb}\right)$, whereas at concentrations of $200 \%$ and $300 \%$ (50 mg. $\mathrm{Kg}^{-1}$ to $75 \mathrm{mg} \cdot \mathrm{Kg}^{-1}$ of Ag; $360 \mathrm{mg}$. $\mathrm{Kg}^{-1}$ to $540 \mathrm{mg} \cdot \mathrm{Kg}^{-1}$ of $\mathrm{Pb}$ ), the thickness of vessels in plants from the Ag treatment was $26 \%$ and $30.1 \%$ higher, respectively (Table 1 ).

Plants subjected to the highest concentrations of $\mathrm{Ag}$ and $\mathrm{Pb}$ had chlorophyll parenchyma thickness 33.7 and $15.57 \%$ higher, respectively than those subjected to the control treatment. Plants grown at concentrations of 25 and $50 \mathrm{mg} \cdot \mathrm{Kg}^{1}$ of $\mathrm{Ag}$ showed chlorophyll parenchyma thickness $15.1 \%$ and $32.8 \%$ higher than those subjected 

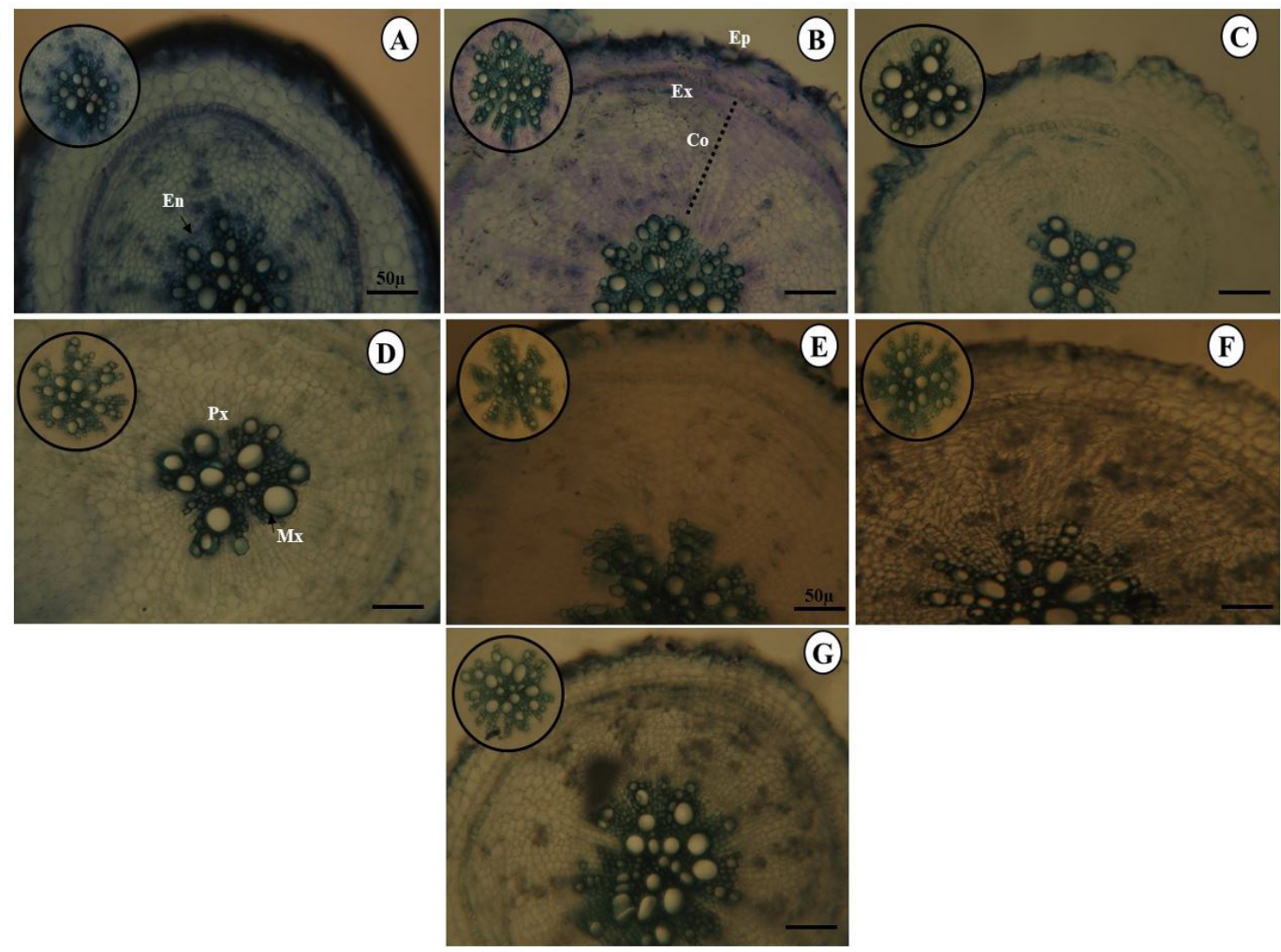

Figure 3. Roots of lettuce under lead and silver nitrate concentrations. A: 0 mg.Kg-1 Pb and Ag; B: 12,5 mg.Kg-1 Ag; C: 25 mg.Kg ${ }^{-1} \mathrm{Ag}$; D: 37 mg.Kg ${ }^{-1} \mathrm{Ag}$; E: 90 mg.Kg- ${ }^{-1} \mathrm{~Pb}$; F: 180 mg.Kg-1 Pb and G: 270 mg.Kg-1 Pb. En: endoderm; Ep: epidermis; Ex: exoderm; Co: cortex;

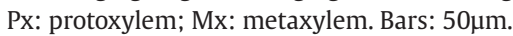

to concentrations of 180 and $360 \mathrm{mg} \cdot \mathrm{Kg}^{-1}$ of $\mathrm{Pb}$, respectively (Table 1 ).

The results of the anatomy of the root tissues for both analyzed factors (metal and Concentration) showed an interaction. The epidermis thickness had a reduction of $65.3 \%$ and $79.9 \%$ in plants subjected to the highest concentrations of $\mathrm{Ag}$ and $\mathrm{Pb}$, respectively, in comparison to the control. Plants subjected to the concentration of $180 \mathrm{mg} \cdot \mathrm{Kg}^{-1}$ of $\mathrm{Pb}$ had the thickness of their epidermal cells increased by $55.6 \%$ in comparison to those from the Ag treatment. Regarding the other concentrations, there was no significant difference (Table 1).

The thickness of the cortical parenchyma cells in plants grown at $\mathrm{Ag}$ concentrations up to $75 \mathrm{mg} . \mathrm{Kg}^{-1} \mathrm{did}$ not differ from that in plants subjected to the control group, except for those grown at the concentration of $50 \mathrm{mg} \cdot \mathrm{Kg}^{-1}$, which, compared to the control, had a decrease of $32.8 \%$ in the thickness of the cortical parenchyma cells. For plants grown at $\mathrm{Pb}$ concentrations, only those from the $540 \mathrm{mg}$. $\mathrm{Kg}^{-1}$ treatment had a reduction (38.1\%) in the thickness of the cortical parenchyma cells in comparison to the control group. At the highest concentrations of the two metals, this variable in plants subjected to $\mathrm{Pb}$ had a reduction of 29.3\% compared to those from the Ag treatment (Table 1 ).
For the thickness of vessels, up to the concentration of $50 \mathrm{mg} . \mathrm{Kg}^{-1} \mathrm{of} \mathrm{Ag}$, there was no significant difference in comparison to the control group, but at the concentration of $75 \mathrm{mg} . \mathrm{Kg}^{-1}$, the vessels were $58.0 \%$ thicker than those in plants grown with no metal. In plants subjected to $180 \mathrm{mg}$. $\mathrm{Kg}^{-1}$ of $\mathrm{Pb}$, there was a vessel thickening of $39.9 \%$, differing from the control group only. Plants grown at 180 and $360 \mathrm{mg} \cdot \mathrm{Kg}^{-1}$ of $\mathrm{Pb}$ had thickness of vessels $31.1 \%$ and $27.2 \%$, respectively, higher than those grown at the same concentrations of $\mathrm{Ag}$ (Table 1 ).

\section{Discussion}

When analyzing the data from the germination physiology experiment in L. sativa seed, it was evident that the ability of the metal to interfere with seed germination and emergence can often be related to seed permeability to heavy metals and internal structure, which, once in contact with the embryo, causes damage to the tissues. The effects on germination may be associated with the fragile seed tegument of L. sativa, increasing the contact of the embryo to the metal and negatively interfering with the speed, time and percentage of germination and emergence. 
Analyzing the phytotoxicity of lead on germination and initial growth of lettuce under laboratory conditions, Pires-Lira et al. (2020) found that seed germinations was affected at higher concentrations of this metal, although they recognized that seedling growth is more sensitive to the effects of heavy metals than seed germination is.

In this research, lettuce seeds germinated in 5 days when in contact with the metals $\mathrm{Pb}$ and $\mathrm{Ag}$ and in 3 days in the absence of the metals. Apparently, this difference may be associated with metals, however, according to the manufacturer, the sativa seeds can germinate in up to 7 days.

Under laboratory conditions, Jelea et al. (2015) verified a reduction in germination with the increase in the concentration of lead nitrate. The decrease in the percentage of germination may be related to the interference of the metal in the activity of amylases and proteases (Nas and Ali, 2018; Boi et al., 2020).

Several studies indicate that silver nitrate is toxic for seeds of species such as barley, wheat, and cruciferous plants, showing that in sensitive species, toxicity is already observed from a silver nitrate concentration of $7.5 \mathrm{mg} . \mathrm{L}^{-1}$ (Vishwakarma et al., 2017). Considering that there was an emergence of the plants, although the maximum concentration ( $75 \mathrm{mg} \mathrm{Kg}^{-1}$ ) used in this study was ten times higher than those observed in other studies with more sensitive plants, it can be assumed that for emergence, lettuce presents good tolerance to silver nitrate. Probably, the studied species has some enzymatic mechanism that can help it to overcome the stress caused by Ag.

Excess metals in plants cause a decrease in their growth due to the inhibition of photosynthesis, hormonal changes and interference in the regulation of mineral nutrition (Rucińska-Sobkowiak, 2016). Due to these factors, even with the chemical fertilization performed in the initial stage of growth, the plants presented characteristics of nutrient deficiency, among which, chlorosis was the most apparent one, showing clear signs of nitrogen deficiency.

Subsequently, the plants responded by increasing the chlorophyll content. The tolerance mechanism of plant species subjected to excess heavy metals is related to their intrinsic, physiological and biochemical response, as well as to the chemical element and its ability of translocation through the plant (Tiwari and Lata, 2018). Changes in the expression of some genes may contribute to the acquisition of higher tolerance (Chen et al., 2019); however, genotypic differences among species and even cultivars allow different physiological responses to chemical agents.

The sensitivity of plants to heavy metals depends on an interrelated network of physiological and molecular mechanisms such as: (i) uptake and accumulation of metals through binding of extracellular exudates and cell wall constituents; (ii) efflux of heavy metals from cytoplasm to extra nuclear compartments including vacuoles; (iii) complexation of heavy metal ions inside the cell of various substances, for example, organic acids, amino acids, phytochelatins, and metallothioneins; (iv) accumulation of osmolytes and osmoproteins and induction of antioxidative enzymes; and (v) activation or modification of plant metabolism to allow adequate functioning of metabolic pathways and rapid repair of damaged cell structures (Cho et al., 2003).
Despite numerous studies, the specific mechanisms involved in heavy metal accumulation and detoxification are yet to be well described. Characterization of these mechanisms could be important in improving the potential of Salicaceae plants for phytoremediation (Cho et al., 2003).

In spite of observing negative effects on the plants subjected to $\mathrm{Pb}$, some defense mechanisms against the phytotoxic agents may have been activated since in longer periods of exposure to the metal, there was a significant increase in plant leaf area and height, even at the maximum used dosage. Thus, the phytotoxic effect of the metals did not negatively affect the plant in longer periods. The seemingly positive responses can be explained by the fact of lettuce plants reduce or neutralize the toxic effects of some metals, which can be reduced by activating plant antioxidant defense systems, reduction in metal transport over long distances, and storage of metals in the vacuoles (Emamverdian et al., 2015).

Different concentrations of metals, among them the $\mathrm{Pb}$, in different species and parts of plants are directly related to the concentrations of metals in the soil. The concentrations of metals may be higher in the cell walls of the root system and lower in the aerial part. In some cases, the metals act positively on the increase of biomass, both in root and aerial part, depending on the species (Eissa and Negim, 2018). These results corroborate the ones obtained in this study, in which either the biomass increase was verified, or no difference was observed between the controls. The metal concentrations increased the root system and, consequently, increased the capacity of water and nutrient absorption, which directly reflected the increase in the aerial part. In sequence, given the increases in biomass in both root and shoot systems, it can be considered that the applied concentrations had no toxic effects on lettuce in longer periods of exposure to the applied metals.

The $\mathrm{Pb}$ interferes with several physiological processes in lettuce, such as the increase of chlorophyll content and leaf and root area; in response, the plant has bigger structures for the accumulation of biomass, considering they can positively interfere with the increase in photosynthesis and water and nutrients absorption, acting with a set of factors that allows this increase.

In a study with lettuce (L. sativa), radish (Raphanus sativus), tomato (Solanum lycopersicum) and ryegrass (Secale cereale), it was verified the maximum accumulation of $\mathrm{Pb}$ in the roots (Rai et al., 2019), suggesting that immobilization may be linked to the amino acid histidine, consisting of a plant strategy to avoid toxicity in parts above ground (Dawuda et al., 2020). Pb detoxification mechanisms also include storage in the vacuole, synthesis of phytochelatins, and binding to glutathione (Pires-Lira et al., 2020).

Even at low concentrations of cadmium, there was a significant increase in Tetraena qataranse biomass production, in both root and shoot (Usman et al., 2019). A similar result was verified in the present study with the increase of lead and silver concentrations, characterizing a stimulating response of adaptation to stress caused by the presence of metal. Usman et al. (2019) point out that in Tetraena qataranse, the metals improved the gas exchange by stimulating the stomatal opening; this condition may 
have stimulated the increase of biomass in the plants analyzed in our study.

Physiological stresses caused by metals to different organisms can be observed to a greater or lesser extent, depending on the response given by the organism. L. sativaproves to be a species tolerant to metals such as Cd and As (Wang et al., 2017; Musa et al., 2017) as well as to $\mathrm{Ag}$ and $\mathrm{Pb}$, as shown in our study, which proves that the changes in seedlings subjected to concentrations of Ag and $\mathrm{Pb}$ vary, occurring in the tissue structure of roots and leaves. The reduction in the root epidermal cell thickness in plants grown at higher concentrations of metals possibly presented oxidative effects by the action of these metals (Ismael et al., 2019; Hamim et al., 2018).

As a survival strategy, some plants increase the thickness of the vascular bundles when subjected to metal concentration (Hamim et al., 2018) to maintain the hydraulic safety by increasing the thickness of the vascular tissue cells, increasing the flow of photo assimilates and nutrients in the vegetable (Pires-Lira et al., 2020). The increase in vessel thickness can be directly related to the increase in shoot mass, in which a proportional increase was observed (Figure 1F), also observed in the increase of vessels (Table 1 and Figure 3 in special G).

In the leaves, the increase in the distance between vascular bundles may have occurred due to the increase in the shoot and leaf area (Figure 1D and Figure 2 in special G) since as the concentrations have increased the distance between vascular bundles followed the same behavior, similar to that observed in leaf area and distance between vessels.

Changes in epidermal cell thickness, both abaxial and adaxial, and in chlorophyll parenchyma can be related to the plant ability to get around the stress caused by the metal (Hamim et al., 2018). It is suggested that the adaptations in the thickness of epidermis and parenchyma may have increased the rate of transpiration and photosynthetic capacity of the plant, which was compensated by the increase in root biomass and consequently increase in water and nutrients absorption, resulting in the increase of biomass in the aerial part.

In summary, lettuce plants subjected to silver nitrate and lead nitrate metals presented phytotoxic effects in the first days up to 15 DAS. However, silver nitrate promoted negative effects in the emergence percentage, reducing the vigor of $L$. sativa seeds with a marked fall in the number of emerged seeds. Despite the initial interference of the metals in the lettuce plants, the final biomass production had no negative interference compared to the control groups (with no metals), proving to be tolerant to high concentrations of Ag and Pb. The 'babá de verão' cultivar has some tissues modified in response to the stress caused by the metals Ag and $\mathrm{Pb}$. Even with no deleterious effects on the biomass production of lettuce plants, because it is an accumulating species, the growth of this vegetable in contaminated soils can lead to serious damage to human and animal health.

\section{Acknowledgements}

The authors would like to thank the Research Support Foundation in the State of Alagoas (FAPEAL).

\section{References}

AZEVEDO, J.A.M., BARROS, A.B., MIRANDA, P.R.B., COSTA, J.G. and NASCIMENTO, V.X., 2019. Biomonitoring of Heavy Metals (Fe, $\mathrm{Zn}, \mathrm{Cu}, \mathrm{Mn}, \mathrm{Cd}$ and $\mathrm{Cr}$ ) in Oysters: Crassostrea rhizophorae of Mangrove Areas of Alagoas (Brazil). Brazilian Archives of Biology and Technology, vol. 62, pp. e19180211. http://dx.doi. org/10.1590/1678-4324-2019180211.

BAGHAIE, A.H. and FEREYDONI, M., 2019. The potential risk of heavy metals on human health due to the daily consumption of vegetables. Environmental Health Engineering and Management Journal, vol. 6, no. 1, pp. 11-16. http://dx.doi.org/10.15171/ EHEM.2019.02.

BARONI, G.R., PEREIRA, M.P., CORREA, F.F., CASTRO, E.M. and PEREIRA, F.J., 2020. Cadmium tolerance during seed germination and seedling growth of Schinus molle (Anacardiaceae). Floresta e Ambiente, vol. 27, no. 2, pp. e20170502. http://dx.doi. org/10.1590/2179-8087.050217.

BOI, M.E., PORCEDDU, M., CAPPAI, G., DE GIUDICI, G. and BACCHETTA, G., 2020. Effects of zinc and lead on seed germination of Helichrysum microphyllum subsp. tyrrhenicum, a metaltolerant plant. International Journal of Environmental Science and Technology, vol. 17, no. 4, pp. 1917-1928. http://dx.doi. org/10.1007/s13762-019-02589-9.

BRASIL. Ministério da Agricultura, Pecuária e Abastecimento, 2009. Regras para análise de sementes. Brasília: Secretaria de Defesa Agropecuária. Mapa/ACS, 399 p.

CHEN, H., LI, Y., MA, X., GUO, L., HE, Y., REN, Z., KUANG, Z., ZHANG, X. and ZHANG, Z., 2019. Analysis of potential strategies for cadmium stress tolerance revealed by transcriptome analysis of upland cotton. Scientific Reports, vol. 9, no. 1, pp. 86. http:// dx.doi.org/10.1038/s41598-018-36228-z. PMid:30643161.

CHO, M., CHARDONNENS, A.N. and DIETZ, K.J., 2003. Differential heavy metal tolerance of Arabidopsis halleri and Arabidopsis thaliana: a leaf slice test. The New Phytologist, vol. 158, no. 2, pp. 287-293. http://dx.doi.org/10.1046/j.1469-8137.2003.00746.x.

CONSELHO NACIONAL DO MEIO AMBIENTE - CONAMA, 2013 [viewed 09 April]. Available from: http://www.ctpconsultoria. com.br/pdf/Resolucao-CONAMA-460-de-30-12-2013.pdf

ĆWIELA̧G-DRABEK, M., PIEKUT, A., GUT, K. and GRABOWSKI, M., 2020. Risk of cadmium, lead and zinc exposure from consumption of vegetables produced in areas with mining and smelting past. Scientific Reports, vol. 10, no. 1, pp. 1-9. http:// dx.doi.org/10.1038/s41598-020-60386-8. PMid:32099081.

DAWUDA, M.M., LIAO, W., HU, L., YU, J., XIE, J., CALDERÓN-URREA, A., WU, Y. and TANG, Z., 2020. Foliar application of abscisic acid mitigates cadmium stress and increases food safety of cadmiumsensitive lettuce (Lactuca sativa L.) genotype. PeerJ, vol. 8, pp. e9270. http://dx.doi.org/10.7717/peerj.9270. PMid:32676218.

EISSA, M.A. and NEGIM, O.E., 2018. Heavy metals uptake and translocation by lettuce and spinach grown on a metalcontaminated soil. Journal of Soil Science and Plant Nutrition, vol. 18, no. 4, pp. 1097-1107. http://dx.doi.org/10.4067/S071895162018005003101.

EMAMVERDIAN, A., DING, Y., MOKHBERDORAN, F. and XIE, Y., 2015. Heavy metal stress and some mechanisms of plant defense response. TheScientificWorldJournal, vol. 756120, pp. 756120. http://dx.doi.org/10.1155/2015/756120. PMid:25688377.

HAMIM, H., MIFTAHUDIN, M., and SETYANINGSIH, L., 2018. Cellular and Ultrastructure Alteration of Plant Roots in Response to Metal Stress. In: D. RATNADEWI and HAMIM. Plant Growth and Regulation - Alterations to sustain unfavorable conditions. IntechOpen. http://dx.doi.org/10.5772/intechopen.79110. 
ISMAEL, M.A., ELYAMINE, A.M., MOUSSA, M.G., CAI, M., ZHAOAB, X. and CHENGXIAO HU, C., 2019. Cadmium in plants: uptake, toxicity, and its interactions with selenium fertilizers. Metallomics, vol. 11, no. 2, pp. 255-277. http://dx.doi.org/10.1039/ C8MT00247A. PMid:30632600.

JELEA, S., JELEA, M. and JELEA, O., 2015. Phytotoxicity of Lead on Lolium perenne $\mathrm{L}$ and Lactuca sativa $\mathrm{L}$ var. capitata: Effects of Germination and Growth. Bulletin UASVM Agriculture, vol. 72, no. 1, pp. 129-135. http://dx.doi.org/10.15835/buasvmcn-agr:11187.

KIM, H., JANG, T., CHAE, H., CHOI, W.J., HA, M.N., YE, B.J., KIM, B.G., JEON, M.J., KIM, S.Y. and HONG, Y.S., 2015. Evaluation and management of lead exposure. Annals of Occupational and Environmental Medicine, vol. 27, no. 30, pp. 30. http://dx.doi. org/10.1186/s40557-015-0085-9. PMid:26677413.

JOHANSEN, D.A., 1940. Plant microtechnique. 2. ed. New York: Mc-Graw-Hill, $523 \mathrm{p}$.

KRAUS, J.E. and ARDUIN, M., 1997. Manual básico de métodos em morfologia vegetal. Rio de Janeiro: EDUR, 25 p.

LABOURIAU, L.G., 1983. A germinação das sementes. Washington: Secretaria Geral da organização dos Estados Americanos. 174 p.

MAGUIRE, J.D., 1962. Speed of germination-aid in selection and evaluation for seedling emergence and vigor. Crop Science, vol. 2, no. 2, pp. 176-177. http://dx.doi.org/10.2135/cropsci1962.00 11183X000200020033x.

MUSA, D.M., GARBA, Y.I., YUSUF, M.S., and DANJUMA, M.S., 2017. Potential of lettuce (Latuca sativa) for phytoremediation of $\mathrm{Cd}$, $\mathrm{Cu}, \mathrm{Cr}$ and $\mathrm{Pb}$ in contaminated soil along river Salanta. Dutse Journal of Pure and Applied Sciences, vol. 3, no. 2, pp. 258-269.

NAS, F.S. and ALI, M., 2018. The effect of lead on plants in terms of growing and biochemical parameters: a review. Shengtai Huanjing Xuebao, vol. 3, no. 4, pp. 265-268. http://dx.doi. org/10.15406/mojes.2018.03.00098.

PENDIAS, K.A. 2010. Trace elements in soils and plant. 4th ed. USA: CRC Press. http://dx.doi.org/10.1201/b10158.

PIRES-LIRA, M.F., CASTRO, E.M., LIRA, J.M.S., OLIVEIRA, C., PEREIRA, F.J. and PEREIRA, M.P., 2020. otential of Panicum aquanticum Poir. (Poaceae) for the phytoremediation of aquatic environments contaminated by lead. Ecotoxicology and Environmental Safety, vol. 193, pp. 110336. http://dx.doi.org/10.1016/j. ecoenv.2020.110336. PMid:32092581.

R CORE TEAM, 2018. R: A language and environment for statistical computing [software]. Vienna, Austria: R Foundation for Statistical Computing. Available from: https://www.R-project.org/.

RAI, P. K., LEE, S.S., ZHANG, M., TSANG, Y. F., and KIM, K. H., 2019. Heavy metals in food crops: Health risks, fate, mechanisms, and management. Environment International, Vol. 125, pp. 365-385. https://doi.org/10.1016/j.envint.2019.01.067

RIBEIRO, B.T., NASCIMENTO, D.C., CURI, N., GUILHERME, L.R.G., COSTA, E.T.S., LOPES, G. and CARNEIRO, J.P., 2019. Assessment of Trace Element Contents in Soils and Water from Cerrado Wetlands, Triângulo Mineiro Region. Revista Brasileira de Ciência do Solo, vol. 43, pp. e0180059. http://dx.doi.org/10.15 90/18069657rbcs20180059.
RUCINSKA-SOBKOWIAK, R., 2016. Water relations in plants subjected to heavy metal stresses. Acta Physiologiae Plantarum, vol. 38, no. 257, pp. 257. http://dx.doi.org/10.1007/s11738-016-2277-5.

SAKAI, W.S., 1973. Simple method for differential staining of parafin embedded plant material using toluidine blue. Stain Technology, vol. 48, no. 5, pp. 247-249. http://dx.doi. org/10.3109/10520297309116632. PMid:4126691.

SILVA, W.R., SALOMÃO, L.C., PEREIRA, D.R.M., OLIVEIRA, H.F.E., PEREIRA, A.I.A. and CANTUARIO, F.S., 2019. Irrigation levels and use of hydro retainer polymer in greenhouse lettuce production. Revista Brasileira de Engenharia Agrícola e Ambiental, vol. 23, no. 6, pp. 406-412. http://dx.doi.org/10.1590/1807-1929/agriambi. v23n6p406-412.

SHAHBAZI, F., GHASEMI, S., SODAIEZADEH, H., AYASEH, K. and ZAMANI-AHMADMAHMOODI, R., 2017. The effect of sewage sludge on heavy metal concentrations in wheat plant (Triticum aestivum L.). Environmental Science and Pollution Research International, vol. 24, no. 18, pp. 15634-15644. http://dx.doi. org/10.1007/s11356-017-9178-z. PMid:28523618.

SHAPIRO, S.S. and WILK, M.B., 1965. An Analysis of variance test for normality. Biometrika, vol. 52, no. 3-4, pp. 591-611. http:// dx.doi.org/10.1093/biomet/52.3-4.591.

SURYAWANSHI, P.V., RAJARAM, B.S., BHANARKAR, A.D. and CHALAPATI RAO, C.V., 2016. Determining heavy metal contamination of road dust in Delhi, India. Atmosfera, vol. 29, no. 3, pp. 221-234. http://dx.doi.org/10.20937/ATM.2016.29.03.04.

TIWARI, S. and LATA, C., 2018. Heavy Metal stress, signaling, and tolerance due to plant-associated microbes: an overview. Frontiers of Plant Science, vol. 9, pp. 452. http://dx.doi. org/10.3389/fpls.2018.00452. PMid:29681916.

TYLOVÁ, E., PECKOVÁ, E., BLASCHEOVÁ, Z. and SOUKUP, A., 2017. Casparian bands and suberin lamellae in exodermis of lateral roots: an important trait of roots system response to abiotic stress factors. Annals of Botany, vol. 120, no. 1, pp. 71-85. http:// dx.doi.org/10.1093/aob/mcx047. PMid:28605408.

USMAN, K., AL-GHOUTI, M.A. and ABU-DIEYEH, M.H., 2019. The assessment of cadmium, chromium, copper, and nickel tolerance and bioaccumulation by shrub plant Tetraena qataranse. Scientific Reports, vol. 9, no. 1, pp. 5658. http://dx.doi.org/10.1038/s41598019-42029-9. PMid:30948781.

VISHWAKARMA, K., SHWETA., UPADHYAY, N., SINGH, J., LIU, S., SINGH, V.P., PRASAD, S.M., CHAUHAN, D.K., TRIPATHI, D.K. and SHARMA, S., 2017. Differential Phytotoxic Impact of Plant Mediated Silver Nanoparticles (AgNPs) and Silver Nitrate $\left(\mathrm{AgNO}_{3}\right)$ on Brassica sp. Frontiers of Plant Science, vol. 8, pp. 1501. http://dx.doi.org/10.3389/fpls.2017.01501. PMid:29075270.

WANG, P., LOMBI, E., SUN, S., SCHECKEL, K.G., MALYSHEVA, A., MCKENNA, B.A., MENZIES, N.W. and ZHAOA, F., 2017. Characterizing the uptake, accumulation and toxicity of silver sulfide nanoparticles in plants. Environmental Science. Nano, vol. 4, no. 2, pp. 448-460. http://dx.doi.org/10.1039/C6EN00489J. PMid:32802334. 